\title{
INDIVIDUALS, CITIZENS AND COLLECTIVITY IN ARCHILOCHUS*
}

Paula da Cunha Corrêa ${ }^{1}$

\begin{abstract}
This paper examines the concepts and terms employed for individuals (proper and ethnic names), citizens (astoí, politai), and the collectivity (dèmos, ethnic names) in the fragments of Archilochus.
\end{abstract}

\section{Keywords}

Archilochus, citizens, collectivity, Archaic Greek poetry

\section{Resumo}

Neste trabalho são examinados os conceitos e as expressões para os indivíduos (nomes próprios e gentílicos), os cidadãos (astoí, polítai), e a coletividade (dèmos, gentílicos) nos fragmentos de Arquíloco.

\section{Palavras-chave}

Arquíloco, cidadãos, coletividade, poesia grega arcaica

\footnotetext{
* The Portuguese version of this paper was presented at the XI Congress of the Brazilian Society of Classical Studies (SBEC) at the University of São Paulo, Dec. 4th, 2017.

${ }^{1}$ Associate Professor, University of São Paulo, São Paulo, Brazil. E-mail: correa@usp.br 
The fragments of Archilochus are populated by a profusion of individuals, which can be characters based on historical people or not, heroes, gods and other mythical beings. Among the gods one counts Zeus', Demeter ${ }^{3}$, Dionysus 4 , Apollo5, Hephaestus ${ }^{6}$, Aphrodite$^{7}$, Ares $^{8}$, Enyalius ${ }^{9}$, Poseidon ${ }^{10}$, a Muse (Fr. 1.2 IEG) and the titan Tantalus (Fr. 91.14 IEG). Of the heroes, we hear of Deianeira (Fr. 286-8 IEG) and Heracles (Fr. 259, 286-9, 324.2 IEG), Erymas (Fr. 25. 8 IEG), Pyrrhus and Eurypylus (Fr. 304? IEG), Telephus (P.Oxy. 4708) and of creatures such as Nessus (Fr. 286, 288) and Achelous (Fr. 286-7 IEG).

A companion and friend who is not spared of the poet's satire is Glaucus, son of Leptines. The discovery and publication of the inscription of Glaucus of Thasos (SEG 14.565; 1T Gerber, 1999) confirmed that behind this character mentioned six times in Archilochus' extant fragments ${ }^{11}$ lived a historical figure, mocked in fragment 117 IEG for his elaborate hairdo:

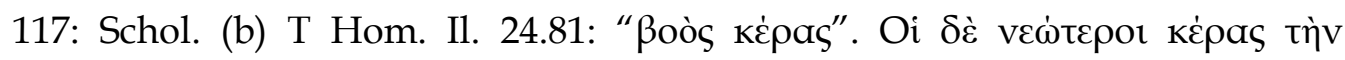

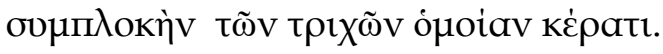

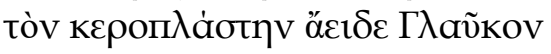
Aрxi入oxos.

Schol. (b) T Hom. Il. 24.81: Later authors use the word horn to describe the horn-like intertwining of the hair.

sing of Glaucus who arranges his hair in horns

So Archilochus." 12

However, the most widely known characters satirized by Archilochus are Lycambes ${ }^{13}$, Amphimedo (Fr. 196.10 IEG) and their daughters, Neoboule (Fr. 118, 196a.24 IEG) and her younger sister (Fr. 196a IEG), whose

\footnotetext{
2 Fr. 25.6, 91.30, 91?, 94.2, 98.7, 13, 122.2, 131.2, 154.5, 157.2, 177.1, 197, 230, 298.1 IEG.

${ }^{3}$ Fr. 169, 322.1 IEG.

${ }^{4}$ Fr. 120.1, 251.1 IEG.

5 Fr. 26.5 IEG.

${ }^{6}$ Fr. 9.11, 108 IEG.

7 Fr. 112.11, 113.6? IEG.

8 Fr. 3.2, 10.8?, 18, 110 IEG.

${ }^{9}$ Fr. 1 IEG.

${ }^{10}$ Fr. 12.1, 192 IEG.

11 Fr. 15, 48.7, (96), 105.1, 117, 131.1 IEG.

12 In this English version of the paper, all translations of Archilochus (fragments and sources) are by Gerber (1999).

${ }^{13}$ Fr. 38, 54.8, 60.2?, 71.1, (172-81 Test.), 172.1 IEG. See also Lycambes' patronymic, Dotades (Fr. 57.7, 151.3? IEG). For the possible meanings of the name Lycambes, see Pickard-Cambridge (1927: 15), West (1974), Nagy (1979) and Miralles-Pòrtulas (1983).
} 
significant names may or may not have served the poet as cover for an attack on members of an actual Parian. Besides the Lycambids, there are many typical characters, such as the glutton Charilaus, son of Erasmon (Fr. 168 IEG):

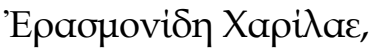

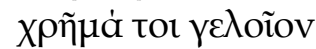 \\ $\dot{\varepsilon} \rho \dot{\varepsilon} \omega$, по入̀̀ $\varphi \dot{i} \lambda \tau a \theta^{\prime} \dot{\varepsilon} \tau a i \rho \omega v$,

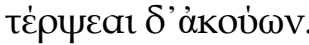 \\ Charilaus, son of Erasmon, \\ by far the dearest of my companions, \\ I shall tell you something funny and \\ you will be delighted to hear it.
}

Just as Lycambes, Neoboule, Amphimedo, Cerycides (Fr. 185 IEG), Pasiphile (Fr. 331 IEG, a friend to all, pasi-phílē) and Leophilus (Fr. 115 IEG), Charilaus (Fr. 168 IEG) seems to have been a significant codename ${ }^{14}$.

At the beginning of this fragment, that may also have been the beginning of the poem, the speaker refers to his addressee by means of a name and patronymic that suggest somebody who is the "grace" or "pleasure of the troops" (kháris + laós). Likewise, the patronymic "son of Erasmon", while imitating the elevated diction of epic, is also suggestive. Some translate it as "son of pleasant", or "Darlingson" (Gerber, 1999), but it could have had more erotic connotations, as in Bonnard ("Fils de l'Amour"15) and in this case perhaps the "funny thing" to be told may be a story involving somebody whose voraciousness may not have been exactly for food.

Nagy (1979: 91ff) compared the name of Achilles (*Akhi-lāuos), as one whose laós suffers, with *Kharí-lāuos, one whose laós rejoices. Nagy relates the patronymic to the "bloom of youth that inspires poetry" (as in Anacreon Fr. 375 PMG), the verb térpomai ("to give/receive pleasure") "conventionally designates the effect of poetry". Odysseus (Od. 9. 3-11) says there is no greater kháris than to dine and listen to the singer, and so Charilaus will also enjoy the pleasure of the banquet, as the "dearest of

\footnotetext{
14 Schneidewin (1838) disposed fragments 168, 170, 171, and 169 IEG in a same group (although separated by asterisks), as Bergk (1882) had Fr. 168, 171, 170, and 169 IEG. Bergk's (1882) ordering of the fragments was followed by Fick (1882), Hoffmann (1898) Diehl (19261' 1936², 19523), Treu (1959), Tarditi (1968) and Adrados (19903). Lasserre's (1958) disposition was adopted by West $\left(1971^{1}, 1989^{2}\right)$ and Gerber (1999). The fragments do not present great textual difficulties, but have been considered strophic and placed among the epodes by West $\left(1971^{1}, 1989^{2}\right)$ and Gerber (1999) or not, according to the interpretation of the meter described by Hephaestion. Cf. Itsumi (2007).

${ }^{15}$ Bonnard (1958): "Fils de l'Amour, Charilaos, jê veux te dire une chose plaisante, ô le plus cher dês amis, et tu serás ravi de l'entendre."
} 
companions". Nagy concludes that Archilochus' epode (Fr. 168 IEG) was directed to philoi in a symposium ${ }^{16}$.

The idea that Charilaus and the patronymic are significant goes back to Liebel (1812), in the least, and many have observed that this is one of the characteristics that Archaic Iambi share with Old Comedy ${ }^{17}$. A fragment of

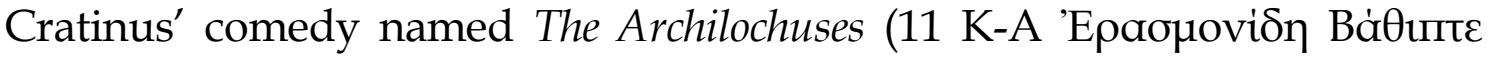
$\tau \tilde{\omega} \mathrm{\alpha} \dot{\alpha} \omega \rho \lambda \dot{\varepsilon} \omega \mathrm{v}$, "O Bathippus, son of Erasmon, with the smooth chin of a boy."18) seems to refer to this poem (Fr. 168 IEG) of Archilochus. If the patronymic ridicules Bathippus' "luxurious nature" 19, the adjective aōróleios, in the sense of that which is unnaturally smooth (unlike a boy's naturally smooth chin), can allude to older men who shear their beards in order to appear prepubescent and thus attract lovers. This same theme might have been present in Archilochus.

The relation of the speaker to Charilaus is not evident. We do not know whether they were friends, or if the designation of Charilaus as "by far the dearest of my companions" is ironical, for while patronymics in elevated genres are "honorable and solemn", in iambic poems they are frequently mocking ${ }^{20}$. Rosen (2007: 26, n. 37) says:

It has been suggested that many iambographic psógoi jâmbicos were composed to be performed in the presence of the targets themselves, and not Always for the purpose of actually injuring them. This notion imagines that the audience, poet, and target alike formed a relatively closed group of philoi, who enjoyed the comic entertainment of creative mutual banter. ${ }^{21}$

What was this "funny thing"? Gentili (1998: 189) supposes a humorous reproach or jesting aimed at a fellow symposiast, and that the funny thing was the dear companion's "polyphagia", Charilaus' "voracious appetite"22. That there are many apostrophes in Archilochus, but particularly in the introduction of fables, favors the hypothesis that this "funny thing" was a

\footnotetext{
${ }^{16}$ For Kantzios (2005: 24) Fr. 168 IEG would also have been part of "friendly bantering in social gatherings".

17 Cf. Rosen (1988).

18 Translated by Storey (2011) who notes that "Bathippus is a documented Athenian name in the 4th c."

${ }^{19}$ Cf. Meineke 1.22, Kock 1.15 apud Rosen (1988: 43).

20 Cf. Gentili and Catenacci (2007).

${ }^{21}$ Nagy (1979: 244-45) quotes Archilochus Fr. 168 IEG in this respect.

${ }^{22}$ Hauvette (1905: 177) believed the "funny thing" was an anecdote, following perhaps Liebel (1812) that identified it" with the anecdote of Aethiops, the Corinthian, in Archilochus Fr. 293 IEG. According to Martino and Vox (1996: 645), the funny thing is buffoonery, for Treu (1959), "it's not a fable, neither a myth, but perhaps a real event". Among so many uncertainties, Bowie (2001: 19) observes that "the clearest point to emerge from the fragments is how the poet draws attention to his role as a story-teller".
} 
fable. The chorus of elders in Aristophanes' Lysistrata begins to tell a fable in a very similar manner ${ }^{23}$ :

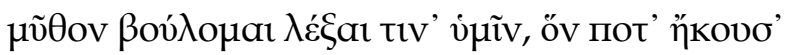 \\ aủiòs ह̌̃tı naĩs ம̋v.

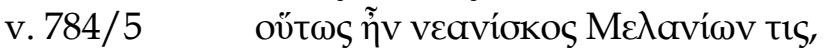 \\ I want to tell you all a tale that once I heard \\ when but a lad. \\ In olden times lived a young man named Melanion. ${ }^{24}$
}

In Aristophanes' Wasps (566), Philocleon refers to Aesop's fables as a "funny thing": "Others tell us stories, others something funny (ti géloion) from Aesop." 25. According to Rankin (1977, p. 92):

In fragment $162 \mathrm{~T}$ [= 168 IEG] Archilochus also uses the technique and mannerism of the story-teller (...). The poet uses epic phrases, but the style is that of a logos; one man is going to tell a story to another, whether it be some anecdote about actual people, or some fable dealing with 'certain' animals (...).

According to Athenaeus (Deipn. 4. 167d), another glutton named in Archilochus' extant fragments is Aethiops, the Corinthian (Fr. 293 IEG) that exchanged the land he was entitled to in Syracuse for a honey cake. Nothing else is heard of him.

Three other characters, Eurymas, Melesander (?) and a herdsman called Phalangios are mentioned in an Oxyrhyncus papyrus fragment in which sexual preferences of Melesander and the herdsman seem to be discussed in the first four verses (Fr. 25 P. Oxy. 2310 fr. 1 col. i.40-48, ed. Lobel):

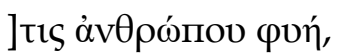

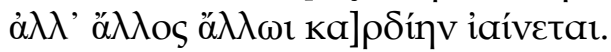

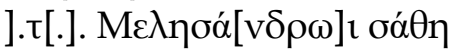

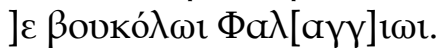

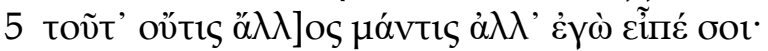

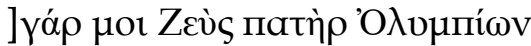

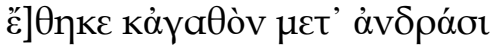

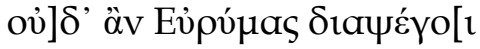

\footnotetext{
${ }^{23}$ Zanetto (2001: 69).

24 Translated by Henderson (2000). Zanetto (2001: 68-9) quotes this passage and also Lysistrata (vv. 805-20). Batezzatto (2009: 139), proposes a different reading: recognizing Homeric echoes in Archilochus Fr. 168 IEG, he suggests that it is not the beginning of a fable, but a parody of the Iliad 1.1-2.

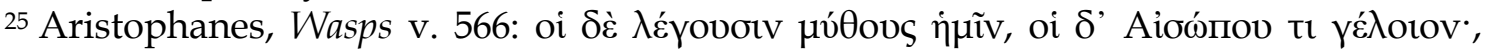
translation by Henderson (1998). See Zanetto (2001: 69) for this reference and also Aristophanes' Wasps 1259-1260.
} 
... human nature, but different people are warmed at heart by different things ... for Melesa(nder) prick ... for the herdsman Phal(ang)ios. I, (no other) prophet, proclaimed (this) to you ... for to me Zeus father of the Olympians . . . made and good among men ... (nor) would Eurymas find fault.

Of the kings and leaders that figure in the fragments of Archilochus, the most well-known is Gyges, king of Lydia. The poem (Fr. 19 IEG) appears to form a priamel, a frequent rhetorical device in Archaic Greek poetry in which a series of values or objects are enumerated and then discarded in favor of a unusual or personal choice. For example, in Archilochus Fr. 114 $I E G$ the speaker first describes a grand general that serves as a foil for the general he prefers and is quite different: small, bow-legged, planted firm on the ground but full of courage. It is also possible that in Archilochus 19 IEG, after a sequence of rejected things the speaker declared his preferences:

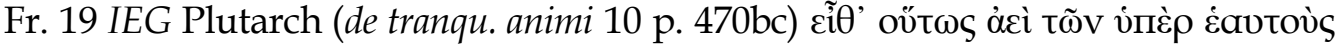

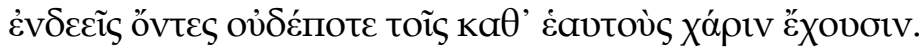

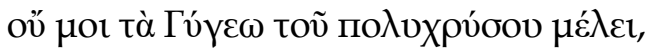

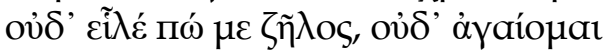

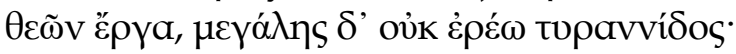

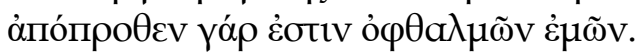

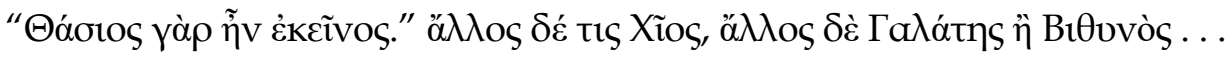

Accordingly, since they always lack what is beyond them, they are never grateful for what befits their station.

The possessions of Gyges rich in gold are of no concern to me, not yet have I been seized with jealousy of him, I do not envy the deeds of the gods, and I have no love of tyranny. That is beyond my sights.

"Yes, since he was a Thasian," someone will say. Yet others, a Chian, Galatian, or Bithynian, are not content if ...

Plutarch quotes these four verses of Archilochus in his treatise (Moralia 10. $470 \mathrm{~b}$ ) as an example of an attitude that, in his view, conduces to tranquility of mind (euthymía): “to examine, if possible, oneself and one's fortunes, but if that is not possible, to observe persons of inferior fortune, and not, as most people do, compare oneself with those who are superior" 26 . According to Plutarch (loc. cit.), the majority (hoi polloî) "through being always conscious that they lack things which are beyond them, they are

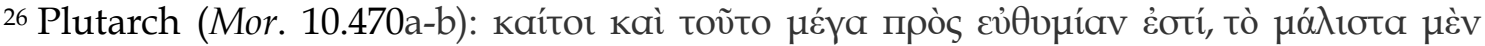

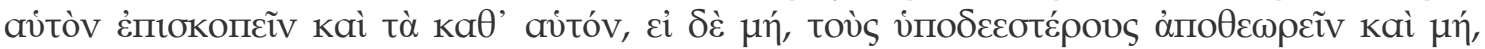

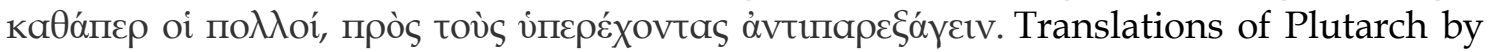
Hembold (1939).
} 
never grateful for what befits their station"27.

Aristotle also quotes the beginning of this poem in the Rhetoric ( $\Gamma 17$ p.1418b23) revealing a fact that Plutarch omitted or simply ignored: who speaks in these verses of Archilochus is Charon, a carpenter. With regard to the éthos ("moral character"), Aristotle (loc. cit.) comments on the necessity of attributing the discourse to a another when one speaks of oneself (to avoid envy, a long discourse or contradiction), or to speak of another without being accused of being offensive or rude. As examples of this, the Philippus (4-7) and the Antidosis (132-39, 141-49) of Isocrates, the beginning of two poems of Archilochus (Fr. 19, 122 IEG) and verses of Sophocles' Antigone (vv. 683-709) are cited.

In the four trimeters of Archilochus Fr. 19 IEG, four objects are discarded by Charon with a final justification. First, the epithet polykhrysos ("of much gold") qualifies Gyges and suggests that all his wealth is was Charon claims he doesn't interest him ${ }^{28}$. Herodotus (I. 12) tells the story of how Gyges became king of Lydia (687-652 BC) and that Archilochus, his contemporary, mentioned him in iambic trimeters. The verses of fragment 19 IEG were soon identified as being those Herodotus referred to and this testimony served as one more evidence for the dating of Archilochus ${ }^{29}$.

The opulence of Asiatic kingdoms was proverbial, as also the treasure of Gyges $^{30}$. Although Charon avows he doesn't care for such riches, neither for the deeds of gods and tyranny, the emphatic repetition of anaphoric negatives betray his disdain, as in the poem on the lost shield (Fr. 5 IEG: tí moi mélei aspis ekeíne,; "What do I care about that shield?") 31.

The second verse begins with the anaphoric repetition of the negative and the $d z \bar{e} l o s$ that Charon says has not gripped him. Dzèlos, that may be translated by "envy" or "jealousy", is generally employed in the positive sense (Chantraine, 19992, s.v.; LSJ). Unlike phthónos, dzēlos and its cognates are frequently an "admiration", "emulation", or "zeal" (cf. zelus) ${ }^{32}$. The verb agaíomai refers to the "the deeds of the gods" meaning "to admire" / "to

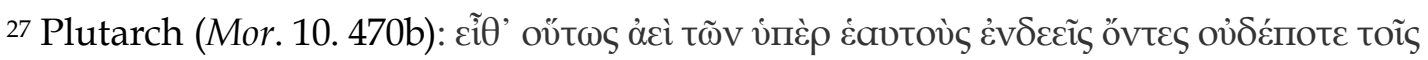
каӨ' غ̇avtoùs Xápiv हैXovoiv.

28 Polúkhrusos, a rare epithet, qualifies Aphrodite (Hesiod, Erga 521) and a Teucrian herald in the Iliad (10.315), both of Asiatic origins.

${ }^{29}$ Cf. Iuba Artigraphus (ap. Rufinum, Gramm. Lat. vi. 563. 18).

${ }^{30} \mathrm{Cf}$. Herodotus (1.14) for the treasures Gyges sent to Delphi.

${ }^{31}$ All ancepi are occupied by long syllables and the "gravity" transmitted by the rhythm may have an ironic effect in this case.

${ }^{32}$ Chantraine $(19992$, s.v.). See Aristotle (Rhet. 1388b) for the distinction between phthónos ("envy") and dzēlos ("noble emulation"), but Hesiod (Erga 195) for dzēlos as "envy", and the Odyssey (5. 118 dzēlémones). 
envy" (cf. LSJ), with the same ambiguity as $d z \bar{e} l o s^{33}$.

Charon concludes the negations by saying: "and I have no love of [the great] tyranny", in what Hippias (FGH 6F6) ${ }^{34}$ holds to be the first reference to "tyranny". Týrannos, a term of Asiatic origins, is "the absolute ruler whose power is not limited by laws"35. But in Archilochus, as in other Archaic Greek texts, a "tyranny" may correspond to a "reign" and in this case its qualification as "great" (megálès) does not imply an absolute power, but one that is vast or extended, such as that of the great Asiatic kingdoms. It is not clear if "týrannos" in the seventh century could have a negative connotation, or not ${ }^{36}$. In Archilochus (Fr. 23. 20-21 IEG), according to the supplements, somebody is exhorted to reign over the city (ánasse) and to be its "tyrant", for thus, "in truth you will be the envy (dz]êtōtós) of many people" 37 . Whether the tyranny in Archilochus Fr. 23. 20-21 IEG is a metaphor or not, it is something that rouses envy ( $d z \bar{e} l o s)$, while in fragment 19 IEG the verb used (eréō", "love") expresses a strong desire ${ }^{38}$.

Finally, the justification for these denials is the carpenter's realist assertion that all of this is out of his reach ("beyond my sights") ${ }^{39}$. If the poem ended at this point it would offer a good example of that which Plutarch proposes (Mor. 10.470bc). From the sixth century onwards the ideal of "civic tranquility" founded on the apology of moderation, of the "middle" (tò méson), becomes a commonplace, a tópos among poets ${ }^{40}$. But if in the seventh century Archilochus did praise moderation in some of his verses, as in fragments 128 IEG, he still seems quite far from a Solon that insists on having refuted tyranny when it was offered to him ${ }^{41}$. Almost all commentaries on Archilochus Fr. 19 IEG suggest that Charon probably

${ }^{33}$ What are these "the deeds of the gods"? In the Iliad (16.120) Ajax calls the deeds of Hector "érga theōn", as he perceives divine intervention, while in the Odyssey (1.338), "érga andrōn te theōn te" are the subject matter of songs. In Archilochus, they might not be related to the deeds and offerings of Gyges (Gerber, 1970: 22).

${ }_{34}$ Apud Argum. in Soph. Oed.Reg. Cf. Et. Gud. (col. 537.26 Sturz), Et. Magn. (p.771.54 Gaisford); Schol. Aesch. Prom. 222 (Dindorf, p.17).

35 Chantraine (19992, s.v.).

${ }^{36}$ Cf. Gerber (1970: 23), Andrews (1956: 20ss). Simonides (Fr. 584 PMG) supra.

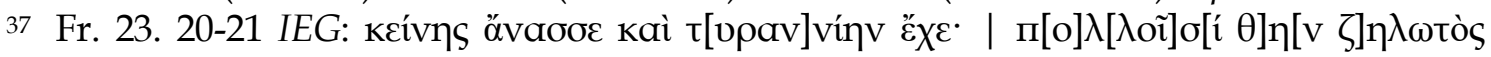

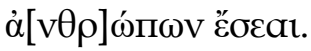

38 Cf. Deioces, a "lover of tyranny" (erastheis tyrannídos), in Herodotus (1. 96. 2).

${ }^{39}$ Although the verb estin is in the singular, it may to refer to all the fore mentioned objects, cf. De Falco and Coimbra (1941), Lasserre (1958), Tarditi (1968), Gerber (1970: 23); Fränkel (1975), Barron-Easterling (1985) and West (1993).

${ }^{40}$ Cf. Solon (Fr. 10. 2 IEG), Theognis (Fr. 219-20, 331-2, 335-6 IEG), Phocylides (Fr. 9 IEG). See also Pindar (P. 11. 50 ss.), where the poet says he wants that which is in his power, censuring tyranny and praising the "middle" (tà mésa).

${ }^{41}$ Solon (Fr. 4c, 6, 32, 33, 34 IEG). For Pindar and Solon's aristocratic conservatism, cf. Gentilli (1988: 149). 
gave a final twist to the poem, and different hypotheses are offered ${ }^{42}$. A late imitation in the Anacreontea (8) ${ }^{43}$ may give us a good clue:

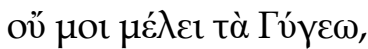

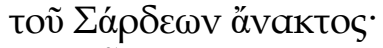

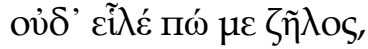

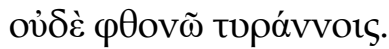

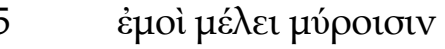

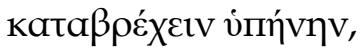

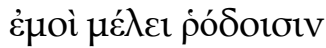

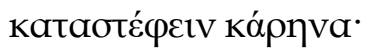

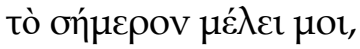

10

tò $\delta$ ' aứpiov tís oĩocv;

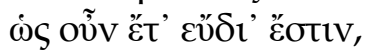

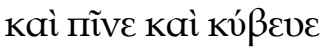

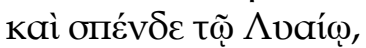

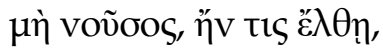

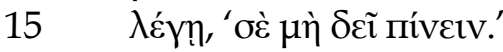

I do not care about the wealth of Gyges, lord of Sardis: I have never envied him, and I have no grudge against tyrants. I care about drenching my beard with perfumes, I care about garlanding my head with roses; I care about today: who knows tomorrow? So while skies are still cloudless drink, play dice and pour libation to Lyaeus, lest some disease come and say, 'You must not drink. ${ }^{44}$

Another political leader in Archilochus is Leophilus. According to Aristotle, Politics 1305a: "...in old times whenever the same man became both leader of the people (dèmagōgós) and general (stratēgós), they used to change the constitution to a tyranny; for almost the largest number of the tyrants of early days have risen from being leaders of the people ${ }^{45}$. This offers a

42 Rankin (1977: 83), Fowler (1987: 72), Pippin-Burnett (1983: 67). Fränkel (1975: 138) suggests Charon doesn't care for a far-away king, but censures a dishonest local "noveauriche" and quotes as a parallel the criticism of Artemon by Anacreon (Fr. 388 PMG). Cf. Fränkel (1955: 57): "<wenn ich aber den NN in seinem übelerworbenen Reichtum und seiner unverdienten Herrlichkeit an meinem Neubau vorüberstolzieren sehe, so läuf mir doch die Galle über --" So sprach der Zimmermann Charon auf Thasos>. Cf. Horace (Ep . 4).

43 Anacreon (Fr. 361 PMG), that develops a similar theme, is also mentioned by Fränkel

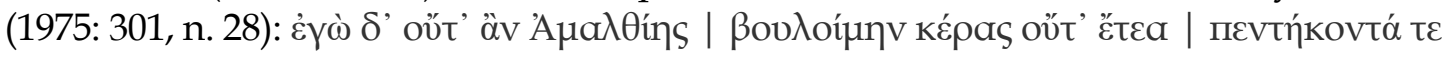

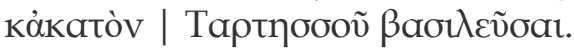

${ }^{44}$ Translation by Campbell (1988). This author of the Anacreontea Fr. 8 PMG could have based himself only on the first verses of Archilochus, and the original may have continued in a different manner; it could have had more erotic ending ("I do not care for Gyges (...) but for the woman....") or a more satiric one, censuring a friend or enemy. For other imitations or parodies of Archilochus Fr. 19 IEG see A. P. 9.110, Gregory Naz. ad. animam suam $84 \mathrm{sg}$; Patr. Gr. 37.683, 1435 Migne.

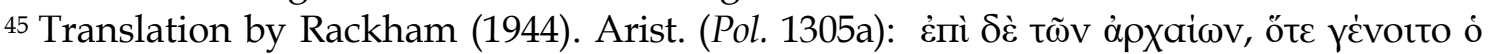

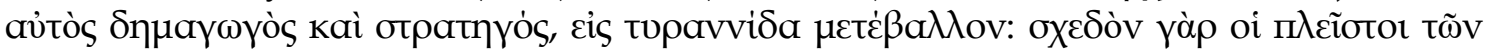


possible reading for Archilochus' Fr. 115 IEG on Leophilus, whose significant name means "dear to the troops" (leós + phílos):

Fr. 115 IEG "Herodian" de figuris (Rhet. Gr. viii.598.16 Walz, iii.97.8 Spengel)

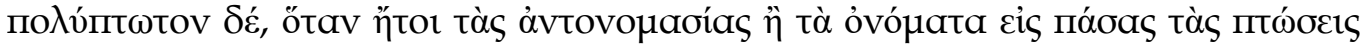

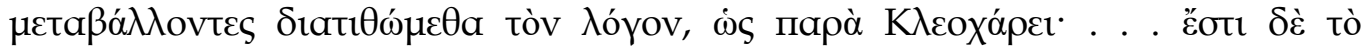

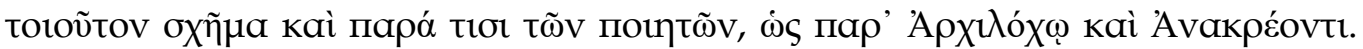

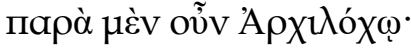

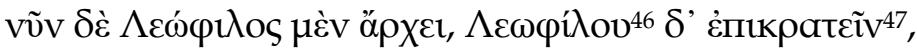

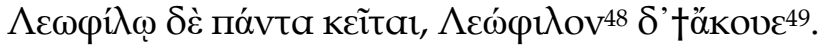

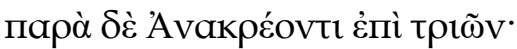

There is polyptoton whenever we arrange what is said by changing all the cases of pronouns or nouns, as in Cleochares: ... Such a figure is found also in some of the poets as in Archilochus and Anacreon. In Archilochus ${ }^{50}$ :

Now Leophilus is in charge, power rests with Leophilus, everything depends on Leophilus, and ... Leophilus.

And in Anacreon with three cases."

In Archilochus Fr. 115 IEG, "Leophilus" may point to someone whose power was conferred to him by the troops (laós), to whom he is dear (philos). Some historians believe that the tyrants in in archaic period emerged as military innovators or entrepreneurs that depended on the support of the troops to govern ${ }^{51}$. Thus, Gallavotti (1949: 71) suggests that these verses of Archilochus were directed against a "real týrranos". It is however possible that "Leophilus" was only a type or a codename for some popular general scorned by the poet.

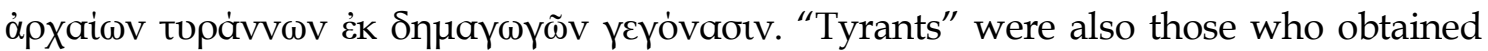
power by "illegitimate", as Gyges (Herodotus 1.14). See also Anthologia Palatina 7.709. For Archaic Greek tyranny, cf. Aristotle (Pol. 5.1310b), Murray (1983: 132-43) and Andrews (1956: 20ss).

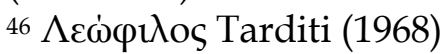

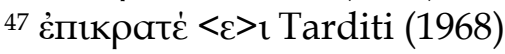

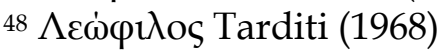

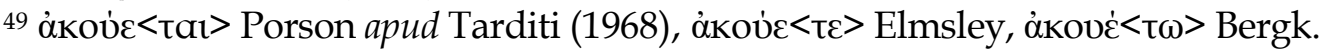

50 There is another polyptoton in Archilochus Fr. 177 IEG, where Zeus is first invoked and then referred to by the second person pronoun in the accusative, nominative, and dative cases. Tarditi (1968) quotes Adesp. 1325 (III p. 629 Kock) that is not a polyptoton, but

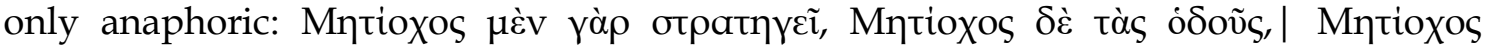

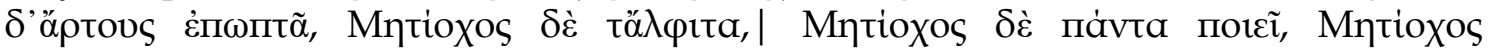

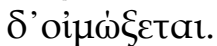

${ }^{51}$ McGlew (1993: 2). 
Other characters with significant names are Cerycides (kērýks + idēs) a "Herald's son" to whom the speaker sends a "grieving message stick" (Fr. 185 IEG) and perhaps Koiranos ("commander", "chief" or "lord"?52), that would have been spared of a shipwreck by Poseidon Hippios (Fr. 192 IEG).

Besides Glaucus, another character that may have been historical is Pericles, a contemporary of Archilochus ${ }^{53}$ to whom the well-known elegy (Fr. 13 IEG) is addressed and who is criticized for his behavior at symposia, according to Athenaeus (Deipn. 1.7f-8b) ${ }^{54}$ :

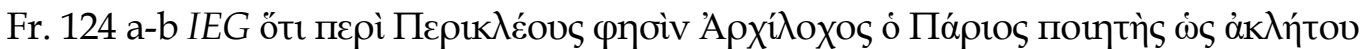

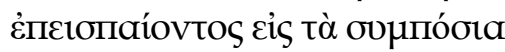

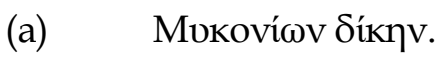

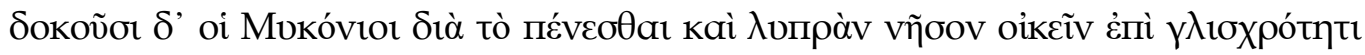

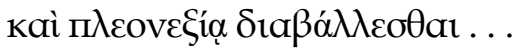

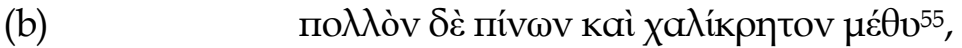

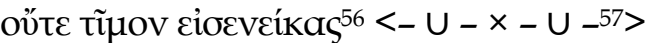

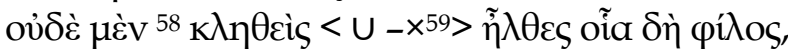

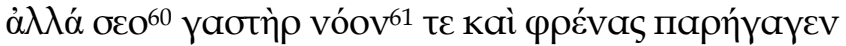

5

eis àvatóínv,

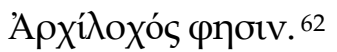

52 Corrêa (2010: 224): “According to Frisk (1960-1972), the term means "commander of troops", associated with herjann (surname of Odin), and Chantraine (1999, s.v. кoipavos) derives it from *koryo, that is a "group of warriors". Therefore, "lord Poseidon" saves another lord, the "Koiranos", by means of a dolphin that in Oppian (Hal. 2.533) is himself a "great lord of the maritime troops".

53 See Pericles in Archilochus (Fr. 13.1, 16, 28.4? IEG), and also Aristides (Or. 46, ii.380.21 Dindorf).

54 This is a difficult and corrupt passage, but the occasion of performance might have been the symposium that is the matter of these verses and the very reason why Athenaeus preserved them.

55 Casaubon, $\mu \varepsilon \theta \dot{u} \omega v$ codd.

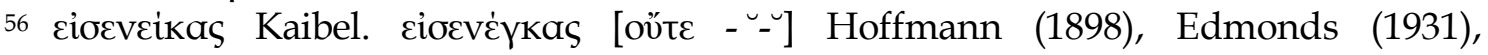

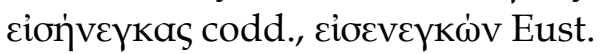

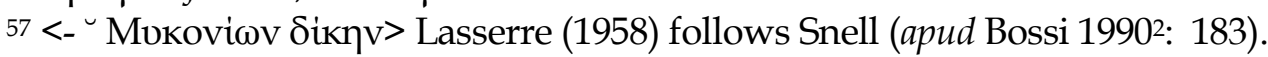

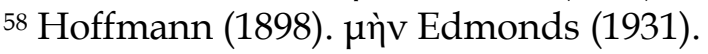

$59<\dot{\varepsilon} \sigma>\tilde{\eta} \lambda \theta \varepsilon \varepsilon \varsigma$ Casaubon, Edmonds (1931), Lasserre (1958), vं $\varphi$ ' $\mu \varepsilon \tilde{\omega v}$ Hiller-Crusius (1897),

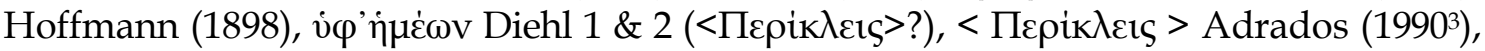

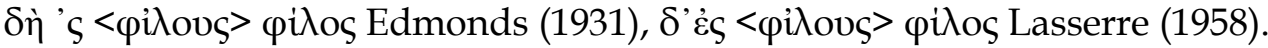

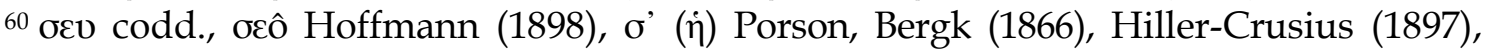

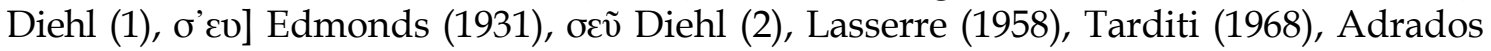
$\left(1990^{3}\right)$.

61 vóv codd., vóov Casaubon

62 There are few commentaries on the text of Archilochus Fr. 124 ${ }^{\mathrm{a}}-\mathrm{b}$ IEG that is problematic. Besides those of Medaglia (1982) and Bossi $\left(1990^{2}\right)$, there are only lexical 
Archilochus, the poet of Paros, speaks of Pericles as bursting into drinking parties uninvited

(a) like the people of Myconos

It seems that the Myconians had a bad name for stinginess and greed because of their poverty and because they lived on a wretched island ...

(b) Although you consumed a large quantity of unmixed wine, you did not contribute to the cost ... nor again did you come invited ... as though a friend, but your belly led astray your mind and wits to shamelessness,

Archilochus says."

There still are in the fragments of Archilochus an Archeanactides (Fr. 122.10 IEG) and maybe an Arthmiades (Fr. 29.2 IEG?), of which we have no information. In the narratives we hear of a Thracian Oesydres (Fr. 91.7?, 92 IEG), Erxies (Fr. 88, 89.28, 110 IEG?), and a son of Pisistratus (Fr. 93a. 4 IEG).

Therefore, in the 294 fragments of Archilochus, excluding the names of all divine figures and heroes, there is a total of 31 proper names of individuals (in 47 occurrences) that provide the verses with a wealth of characters and types comparable to those found in Old Comedy: slaves, carpenters, prostitutes, herdsmen, soldiers, kings, generals, musicians, and soothsayers, in a spectrum that reaches all, from the lowest to the highest strata of society ${ }^{63}$.

As for the anonymous citizen and the collectivity, how does Archilochus represent them? In her recent book, Blok (2017) analyses the concept of citizenship in Classical Athens. As in the 2005 article, Blok examines the vocabulary of citizenship in Homer, Hesiod, the Homeric Hymns, and then focuses on Solon, Pindar, Simonides and Theognis. Previously, Lévy (1985) and Casevitz (2002), among others, also studied the same terms without, however, undertaking a thorough scrutiny of the archaic melic, iambic and elegiac fragments. Due to the scope of this paper, we shall restrict this survey to the occurrences of astoí, politai and dèmos in Archilochus.

notes in Hauvette (1905), Scherer (1964) and Page (1964), and a brief commentary in Fränkel (1975: 145) who observes that Lasserre (1950: 120-121) considers патрó $\theta \varepsilon v$

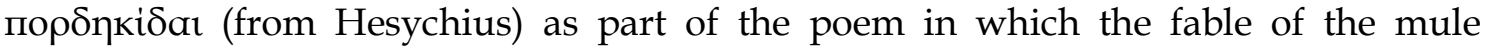
(Babrius 62 Perry) would have been narrated. Cf. Medaglia (1982: 117), Aristides (Or. 46. 11 p. 380 Dindorf).

${ }^{63}$ Cf. Pickard-Cambridge (1927), West (1974), Moulton (1981) and Rosen (1988). 
Until the second half of the fifth century B.C., astoi and politai only occur in the plural, and in archaic poetry astoi is the most frequently employed of the two terms ${ }^{64}$. However, in the Classical period, from Aeschylus onwards politai becomes the most commonly used designation for citizens, being later superseded by the use of the ethnic names (as Athenaíoi for Athenian citizens $)^{65}$.

According to Aristophanes of Byzantium (s.v. áotós), there was no difference between the use of the terms astoi and politai. But Blok (2005: 17) noted that a scholium to Hesiod's Works and Days (Schol. In Hes. Erg. 225) offers a means of differentiation: "the astós is the opposite of the ksénos, and the one who is away from his country (apódemos) is the opposite of the one who is in his own country (éndèmos)". Thus, although astós and politès were very similar, astós was the marked term, used to make a contrast and "where emphasis was intended with a Strong connotation of 'belonging to us'" 66 .

In the remaining fragments of Archilochus there are only two occurrences of astoí, in Fr. 170 and 133 IEG. Hephaestion (Ench. 15. 2) quotes fragment 170 IEG in which "citizens" (astô) and "the majority" (hoi polloi) are mentioned:

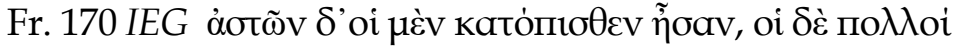

some of the citizens were behind, but the majority ...

The second occurrence of astoí is in verses preserved by Stobaeus (4. 58. 4):

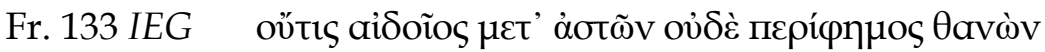

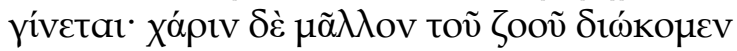

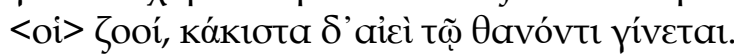

Once dead no one is held in respect among the citizens even though he be powerful (?). Instead we the living curry the favour of the living and the dead are always the worst off.

Unfortunately we have no more than this that tells us very little about who were theses citizens and what they did. There is no evident marked use of astoi to draw a contrast between those who belong to the city and foreigners in Fr. 170 IEG, no indication of genre, nor of sociopolitical ranking, and in what is left of both poems, astoi appears to be simply a term that designates the inhabitants of a urban center collectively ${ }^{67}$. In fragment 133 IEG, astoi

\footnotetext{
64 Blok (2005: 15).

65 Blok (2005: 16).

$66 \operatorname{Blok}(2005: 17)$.

${ }^{67}$ The term "ásty could be used as a synonym for polis, but it could also indicate with
} 
may have been used because it was the most common term, because of the alliteration with aidoîs, or perhaps to mark these dead as "belonging to us", and therefore deserving our respect, fame and grace (aidōs, phèmé, kháris) ${ }^{68}$.

As astoi, politai only occurs in the plural in the Archaic period, with the exception of a proper name in Homer. Likewise, politai in the Archaic texts is a collective term for the inhabitants of the pólis, but without the political implications of citizens rights and obligations that the term will acquire later in the fifth, and specially after the fourth century B.C. when politess (in the singular) becomes the most common way to refer to a free citizen with specific rights and duties ${ }^{69}$.

There is only one occurrence of politai in Archilochus. In Aristophanes (Peace, 603-4), Hermes says: "Farmers most wise, take note of my words if you wish to hear how Peace has disappeared." 70 . A scholium to Aristophanes explains:

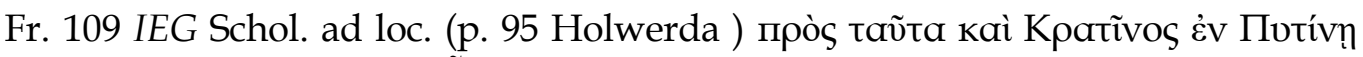

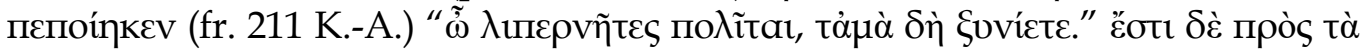
Apxilóxov.

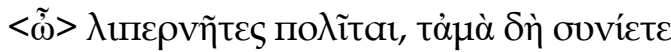

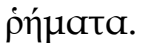

With reference to this Cratinus in Pytine (211 K.-A.) has composed: "Indigent citizens, take note of my words." And this comes from Archilochus:

Indigent citizens, take note of my words. ${ }^{71}$

emphasis the urban center in contrast to the countryside or a smaller town nearby" (Blok, 2005: 17).

68 These verses also express Archilochus' so-called realism, in comparison to Tyrtaeus Fr. 12. 23-34 IEG, in which those killed in combat are said to receive aidoss and are honored after their death (Cairns, 1993: 167, n. 64). Cf. Archilochus Fr. 134 IEG: Schol. Hom. Od. 22. 412 "it is not sanctioned by divine law to boast over the dead") Hence Archilochus says: 'for it is not good to jeer at the dead'"

${ }^{69}$ Blok (2005: 12-14).

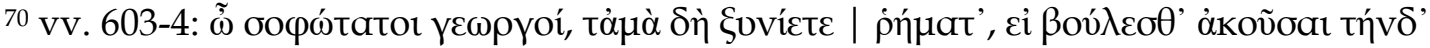

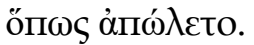

${ }^{71}$ For Gerber (1999) бофஸ́tator in Aristophanes (Pax 603ss.) “is apparently an error for

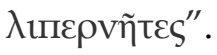


Gerber (1999) suggests that this fragment 109 IEG of Archilochus could have been part of an exhortation to emigrate to Thasos. It could well have been a grave poem, as were many of Archilochus' trochaic tetrameters, and lack of food and resources has been pointed out as one of the causes of the seventh century migrations in Greece.

The term politai in Archilochus 109 IEG does not indicate gender, nor social status, and as in most of the early occurrences, it is qualified by an adjective that defines it, since at first it only indicates the inhabitants of the pólis 72. One may note how the beginning of this speech with an interjection, adjective and the vocative politai reproduces the pattern of the political speeches addressed to citizens gathered in assemblies, typical of later oratory.

Another term used by Archilochus for the collectivity is dèmos. In the fifth century Athens dèmos was usually employed for free citizens of inferior socioeconomic position, and depending on the context, it could be pejorative $^{73}$. Donlan (1970: 382) in his study on demos affirms that in Homer ${ }^{74}$, Hesiod and the Homeric Hymns the word is not used in a derogatory sense, neither does it have sociopolitical connotations, but that it referred to the community as a whole, excluding its leaders 75 . However, if the leaders were not counted as part of the demos, the term did involve a political distinction.

The dèmos is a district, a physical space, and also the people who inhabit it. In Archaic literature, in Homer, Hesiod and other poets, dèmos could designate the people in opposition to the kings (basileís) and leaders (LSJ sv $\delta \tilde{\eta} \mu \mathrm{s})$, as the laós in the army defines the mass of soldiers in contrast to the commanders and heroes. In Archaic communities, "institutions are informal and dominated by the elite. Yet a closer look reveals that the role of demos and assembly is significant" (Raaflaub, 1998: 182), although the kings (basileis) were responsible for political decisions, war and the administration of justice. Later, dèmos comes to mean "the masses", or the "non-elites" that will dispute the power in the cities with the members of aristocracy, the so-called "noble" (esthloi) and "good" (agathoi $)^{76}$.

\footnotetext{
72 Blok (2005: 14).

73 Donlan (1970: 382).

${ }^{74}$ Except in the Iliad (2.198-206).

75 Donlan (1970: 385) however notes a larger distance and tension between the demos and its leaders (the kings) in Hesiod's Works and Days.

${ }^{76}$ Hall $(2007: 46,48)$.
} 
There are three occurrences of dèmos in Archilochus' extant fragments (Fr. 14.1, 182.1 e 207 IEG). Hephaestion (de poem. 7.2) quotes the following verses:

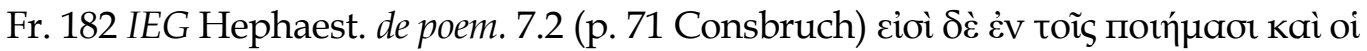

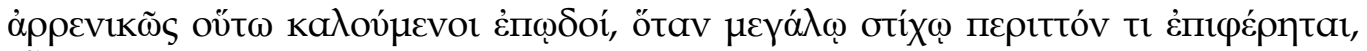

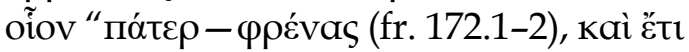

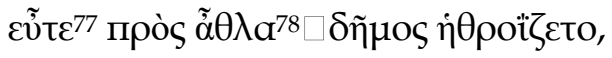

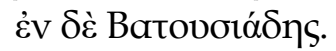

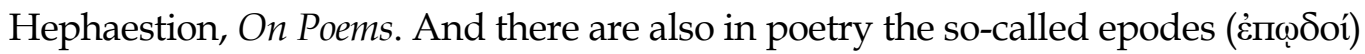
with masculine termination, whenever some surplus is added to a long line, such as (fr. 172.1-2) and also

when the people gathered for the games, and among them Batousiades

There is no explicit negative connotation of demos in this brief fragment: it only tells us that among the people gathered for the games there was this Batousiades. However, according to Hesychius (Archilochus Fr. 183 IEG $^{79}$ ), Batousiades was a seer, son of Selleus, and perhaps the same seer that Aristides says Archilochus slandered:

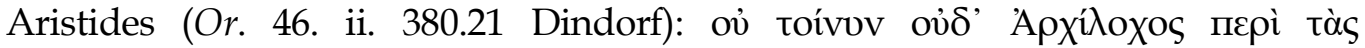

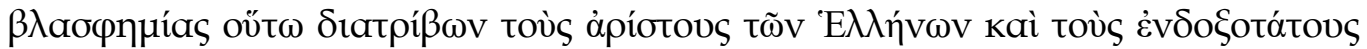

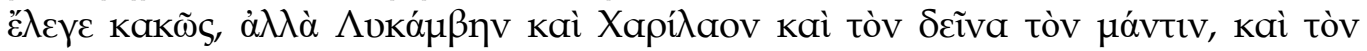

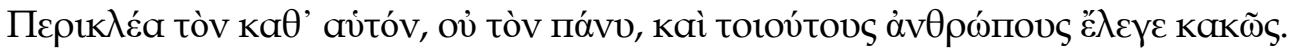

Therefore even Archilochus who was so involved in defamation did not slander the best and most distinguished of the Greeks, but he slandered Lycambes, Charilaus, so-and-so the seer [Fr. 182 IEG?], Pericles-his contemporary, not the famous one-and such men.

If "son of Sellus" (Sellêideō) is a "mock patronymic" referring to the Selloi who were prophets of Zeus in Dodona (Gerber, 1999), then the fact that this Batousiades is "among the demos" might bear a negative connotation to the demos, since the Selloi are described in the Iliad as prophets with unclean feet that sleep on the ground ${ }^{80}$.

In Archilochus Fr. 14 IEG, that many considered as part of the "Elegy to Pericles" (Fr. 13 IEG), Aesimides is adverted:

$77 \varepsilon \tilde{u}$ tı vel $\varepsilon \tilde{u}$ toı codd. corr. Bentley.

$78 \tilde{\alpha} \varepsilon \theta \lambda a$ codd. corr. Fick.

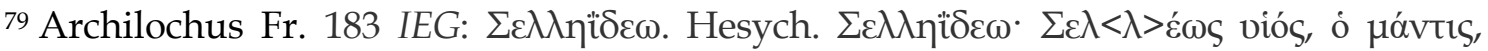

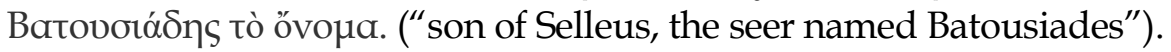

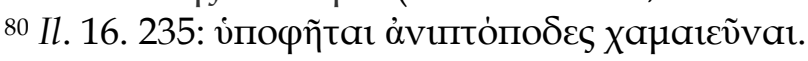




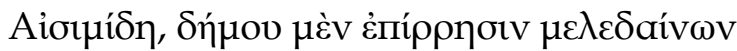

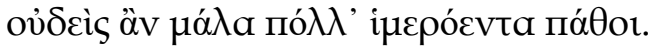

No one, Aesimides, will experience very many delights, if he is concerned about the people's [dèmou] censure.

This "censure" of the demos the speaker advises Aesimides to ignore is epirrēsis, a term glossed in ancient lexica by psógos and kakēgoría ${ }^{81}$, that are frequently associated to iambi. Implicit in the advice to ignore the censure of the demos is its power and the fear it evokes.

Who are these two, the speaker and Aesimides? Could they be leaders that distinguish themselves from the others, the speaker considering Aesimides and himself apart from the demos to which they should not lend their ears? If Aesimides were a man of demos, the advice given would be simply not to heed the opinion (or censure) of others in general. However, if Aesimides were a companion and a member of the speaker's hetairia, the excess of pleasure he avoids for fear of the people's scorn might have been not very different from that which Solon later reproaches in the Athenian leaders: (Fr. 4. 7-10 IEG):

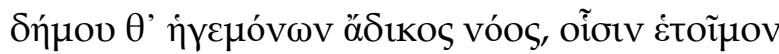

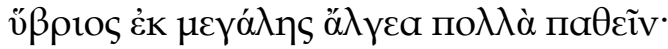

10

oủ үà

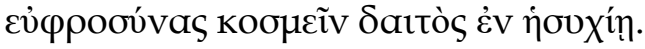

and the mind of the people's [démou] leaders is unjust; they are certain to suffer much pain as a result of their great arrogance. For they do not know how to restrain excess or to conduct in an orderly and peaceful manner the festivities of the banquet that are at hand ...82

The third occurrence of demos in Archilochus was registered by Eusthatius in his commentary on the Iliad (23. 775 (iv.836. 1 V.d.Valk)). Eusthatius does not quote verses, but just says Archilochus called a woman (Neobula?) "a revolting woman, fat about the ankles" 83 and "a public woman" (Fr. 207 IEG dèmos), "i.e., common property of the démos" (koinèn tōi dèmōi), "a worker for hire", and "froth of defilement", "on the analogy of froth of the sea, and such like" (Fr. 206-209 IEG).

According to Donlan (1970: 386 n.16), dèmos occurs in Archilochus in the sense of the non-differentiated population, unlike its meaning in Tyrtaeus Fr. 4.5 IEG where the "men of the demos" would include all free citizens except the leaders (as in Homer), but these would already represent a

81 Orion 55.22 Sturtz, Et. Gen., Et. Mag. s.v.

82 Translated by Gerber (1999b).

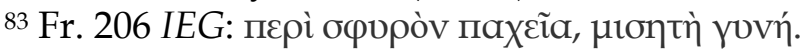


constitutional entity with defined functions, rights and responsibilities ${ }^{84}$. However, in another poem of Tyrtaeus, in fragment 12.15 IEG demos is used in the broader sense and without the distinction of leaders, as in Callinus Fr. 1 IEG, demos refers to the city or its population as a whole.

Therefore, in spite of the meager evidence, it is possible that demos in Archilochus distinguished the people from the leaders, with a social connotation. In Alcman (Fr. 17. 4-8 PMG), however, the social differentiation is clear. According to Athenaeus (Deipn. 10. 416cd (ii 405s. Kaibel)), Alcman declares his gluttony in there verses: a great caldron will soon be full of pea soup ....

5

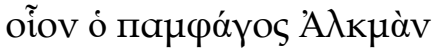

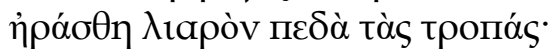

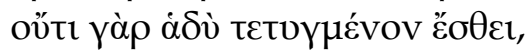

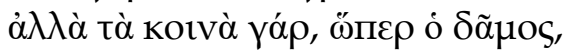

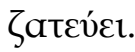

the kind that Alcman, who eats everything, loves hot after the solstice: he eats no (sweet confections?) but looks for common fare like the people [dāmos]. ${ }^{85}$

The characterization of the speaker in Alcman as a pamphágos who eats all, and that prefers pea soup, one of the most popular dishes and that is here qualified as something "common" that the dāmos ( = demos) appreciates, marks and opposes the demos ("people") to those who like "sweet confections".

In sum, demos in the sense of the inhabitants, and not the inhabited space, may be employed since Homer both in a more general and undifferentiated manner, and with social and/or political connotation ${ }^{86}$. The term could be pejorative or not, depending on the literary genre, the context, the occasion of performance and the poet's ideology.

The occurrences of dèmos in Archilochus are relatively rare when compared to the number of individual characters that are named (whether the names denote real people, are significant codenames, or simply name fictitious characters). Archilochus refers to a collectivity most commonly by the ethnic that makes no sociopolitical distinctions and is more concrete. There are references in the poems to Thasians (Fr. 20, 91.44?, 92 IEG), Naxians (Fr. 89.6 IEG), Thracians (Fr. 42.1, 93.6 IEG), from Torone? (Fr. 89.20 IEG), Magnesian (Fr. 20 IEG), Maronites (Fr. 291

\footnotetext{
84 Donlan (1970: 385-6).

85 Translated by Campbell (1988).

86 Contra Donlan (1970: 387).
} 
IEG), Panhellenics (Fr. 102 IEG) and Bisaltae (Fr. 92 IEG?) ${ }^{87}$. Ethnics are used in Archilochus to designate groups, but also individuals, such as Saian (Fr. 5.1 IEG), a Phrygian (Fr. 42.2 IEG) a Carian (Fr. 216 IEG) and a Karpathian (Fr. 248 IEG). The presence and frequency of proper names, in comparison to terms that refer to the citizen and/or the collectivity depend largely on the genre of the discourse and the occasion of performance.

Although Archilochus mentions the island of $\operatorname{Paros}^{88}$, not a single allusion or address to his fellow Parians is left in the remaining fragments. One must not rely on arguments ex silentio, but one plausible reason for this is perhaps because the poet addressed the parians directly, and therefore when he did not cite proper names, he used pronouns or astoi (and less frequently politai) for the group, resorting to ethnics to mark those who do not "belong to us": the others, the foreigners.

\section{References}

\section{Editions of Archilochus}

ADRADOS, F. R. Líricos Griegos I: Elegiacos y Yambógrafos Arcaicos. Barcelona: Ediciones Alma Mater, 1956-1976 (1 ${ }^{\text {st }}$ ed.); Madrid: Consejo Superior de Investigaciones Científicas, 1990 (3rd ed.).

BERGK, Th. Poetae Lyrici Graeci. vol II. Leipzig: B. G. Teubneri, 18824, 1915.

BRUNCK, R. F. P. Analecta Veterum Poetarum Graecorum. Strassburg: 1785.

BUCHHOLTZ, E. Anthologie aus den Lyrikern der Griechen. Leipzig: B. G. Teubner, 1886.

CRÖNERT, G. Archilochi Elegiae. (Auszug aus d. Habilitationsschrift), Göttingen, 1911.

DEGANI, E. Poeti greci giambici ed elegiaci. Milan: Mursia, 1977.

DIEHL, E. Anthologia Lyrica Graeca. Leipzig, B. G. Teubner, 1925 (1 ${ }^{\text {st }}$ ed.), 1936 ( $2^{\text {ond }}$ ed.), 1952 ( $3^{\text {rd }}$ ed.).

\footnotetext{
87 There are also in Archilochus references to an Ismaric wine (Fr. 2.2 IEG), a Cretan law (or musical nómos? Fr. 232 IEG), and a Prienian ass (Fr. 43.2 IEG)

88 Thasos is the most frequently mentioned city (Fr. 21.22, 89.19, 93.6, 96.97, 102, 103.2, 104.2, 228, 291, 295b IEG).
} 
EDMONDS, J. M. Greek Elegy and Iambus. London, Heinemann, 1931.

De FALCO, V. and A. de FARIA COIMBRA. Os Elegíacos Gregos de Calino a Crates. São Paulo: Brusco, 1941.

FARNELL, G. S. Greek Lyric Poetry: a complete collection of the surviving passages from the Greek songwriters. London: Longmans Green \& Co., 1891.

GAISFORD, T. Poetae Minores Graeci. Vol I. Leipzig: Kuhn, 1823.

GERBER, D. E. Greek Iambic Poetry from the seventh to the fifth centuries B. C. Cambridge, Mass., London: Harvard University Press, 1999.

HILLER, E. Anthologia Lyrica Graeca sive Lyricorum Graecorum Veterum praeter Pindarum. Leipzig: B. G. Teubner, 1890.

HILLER, E. and O. CRUSIUS. Anthologia Lyrica Graeca sive Lyricorum Graecorum Veterum praeter Pindarum. Leipzig: B. G. Teubner, 1897 (4th ed.).

HUDSON-WILLIAMS, T. Early Greek Elegy. Cardiff: University of Wales Press Board \& Humphrey Milford, 1926.

LASSERRE, F. and A. BONNARD. Archiloque: Fragments. Paris: Belles Lettres, 1958.

LIEBEL, I. Archilochi Reliquiae. Leipzig: Sommer, 1812 (1st ed.); Vienna: Johann Bartholomäus Zweck, 1818 (2ond ed.).

MARZULLO, B. Frammenti della lirica greca. Florença: Sansoni, 1965-1967 (2ond ed.).

SCHNEIDEWIN, F. G. Delectus Poesis Graecorum Elegiacae, Iambicae, Melicae. Göttingen: Vandenhoeck et Ruprecht, 1838.

SNELL, B. and S. FRANYÓ. Frühriechische Lyriker, II. Die Jambographen. Berlin: Akademie Verlag, 1972.

TARDITI, G. Archiloco. Roma: dell' Ateneo, 1968.

TREU, M. Archilochos. Munique: Ernst Heimeran, 1959

WEST, M. L., Iambi et Elegi Graeci ante Alexandrum cantati. Oxford: Oxford University Press, 1971 (1 ${ }^{\text {st }}$ ed.), 1998 (2ond ed.). 
ANDREWES, A. The Greek Tyrants. London: Hutchinson's University Library; New York: Longmans, Green \& Co., 1956.

BARRON, J. P. e EASTERLING, P. E. Archilochus. In EASTERLING, P. e B. M. W. KNOX (edd.), The Cambridge History of Classical Literature I. Greek Literature. Cambridge: Cambridge University Press, 1985.

BATTEZZATO, L. Meter and Music. In BUDELMANN, F. (ed.) The Cambridge Companion to Greek Lyric. Cambridge: Cambridge University Press, 2009, pp.130-146.

BLOK, J. Becoming Citizens. Some Notes on the Semantics of "Citizen" in Archaic Greece and Classical Athens. Klio, vol. 87, 2005, pp. 5-40.

BLOK, J.Citizenship in Classical Athens. Cambridge: Cambridge University Press, 2017.

BOSSI, F. Studi su Archiloco. 2a ed. Bari: Adriatica, 1990.

BOWIE, E. Early Greek Iambic Poetry: The Importance of Narrative, In CAVARZERE, A., ALONI, A. \& A. BARCHIESI (edd.) Iambic Ideas; Essays on a Poetic Genre from Archaic Greece to the Late Roman Empire. Lanham, Boulder, New York, Oxford: Rowman \& Littlefield, 2001, pp. 1-27.

CAMPBELL, D. A. Greek Lyric Poetry: A Selection of Early Greek Lyric, Elegiac and Iambic Poetry. (2a ed.) Bristol, Bristol Classical Press, 1967-1982.

CAMPBELL, D. A. Greek Lyric, Volume II: Anacreon, Anacreontea, Choral Lyric from Olympus to Alcman Anacreon. Edited and translated. Cambridge, Mass.; London: 1988.

CASEVITZ, M. L'évolution de la citoyenneté en Grèce d'après le vocabulaire. In: RATTI, S. (ed.) Antiquité et citoyenneté. Actes du colloque international de Besançon (3-5 novembre 1999) Besançon: Institut des Sciences et Techniques de l'Antiquité (Collection « ISTA », 850), 2002, pp. 93-104.

CHANTRAINE, P. Dictionnaire étymologique de la langue grecque. Paris: Klincksieck, 1999 (2a ed.).

CORRÊA, P. Da Cunha. Armas e varões; A guerra na lírica de Arquíloco. 2a ed. rev. e aument. São Paulo: Edunesp, 2009.

CORREAA, P. Da Cunha. Um Bestiário Arcaico. Fábulas e imagens de animais na poesia de Arquíloco. Campinas: Editora Unicamp, 2010. 
DEGANI, E. and G. BURZACCHINI. Lirici Greci. Florença, La Nuova Italia, 1977.

DONLAN, W. Changes and Shifts in the Meaning of Demos. La Parola del passato. Rivista di studi antichi, vol. 25, 1970, pp. 381-95.

FICK, A. F. "Die Sprachform der altionischen und altattischen Lyrik", Beiträge zur Kunde der Indogermanischen Sprachen, vol. 11, 1886, pp. 242-72; vol. 13, 1888, pp. 173-221.

FISHER, N. and H. van WEES (edd.) Archaic Greece: New Approaches and New Evidence. London: Duckworth, 1998.

FOWLER, R. L. The Nature of Greek Lyric. Three Preliminary Studies. Toronto, Buffalo: University of Toronto Press, 1987.

FRÄNKEL, H. Wege und Formen frühgriechischen Denkens. München: Beck, 1955.

FRÄNKEL, H. Early Greek Poetry and Philosophy: a history of Greek epic, lyric, and prose to the middle of the fifth century. Trad. M. Hadas e J. Willis. Oxford: Basil and Blackwell, 1975.

GALLAVOTTI, C. Il Tirrano di Archiloco. La Parola del passato. Rivista di studi antichi, vol. 4, 1949, pp. 69-71.

GENTILI, B. Poetry and its Public in Ancient Greece from Homer to the Fifth Century. Trad. T. Cole. Baltimore, London: Johns Hopkins University Press, 1988.

GENTILI, B. and C. CATENACCI. Polinnia; Poesia Greca Arcaica. MessinaFirenze: Casa Editrice G. D'Anna, 2007 (3a ed.).

GERBER, D. E. Euterpe: An Anthology of Early Greek Lyric, Elegiac and Iambic Poetry. Amsterdã: Adolf M. Hakkert, 1970.

GERBER, D. E. Greek Elegiac Poetry From the Seventh to the Fifth Centuries $B C$. Edited and translated. Cambridge, Mass., London: Harvard University Press, 1999b.

HALL, J. M. Polis, Community, and Ethnic Identity, In SHAPIRO, H. A. (ed.) The Cambridge Companion to Archaic Greece. New York: Cambridge University Press, 2007, pp. 40-60.

HAUVETTE, A. Archiloque, sa vie et ses poésies. Paris: Fontemoing, 1905. 
HEMBOLD, W. C. Plutarch, Moralia, Vol. VI; Can Virtue Be Taught? On Moral Virtue. On the Control of Anger. On Tranquility of Mind. On Brotherly Love. On Affection for Offspring. Whether Vice Be Sufficient to Cause Unhappiness. Whether the Affections of the Soul are Worse Than Those of the Body. Cambridge, Mass.: Harvard University Press, 1939.

HENDERSON, J. Aristophanes, vol. II: Clouds. Wasps. Peace. Edited and Translated. Cambridge, Mass.; London: Harvard University Press, 1998.

HENDERSON, J. Aristophanes, vol. III: Birds. Lysistrata. Women at the Thesmophoria. Edited and Translated. Cambridge, Mass.; London: Harvard University Press, 2000.

HOFFMANN, O. Die griechischen Dialekte in ihrem historischen Zusammenhange (III): Der Ionische Dialekt. Göttingen: Vandenhoeck \& Ruprecht, 1898.

HUMMEL, P. Les composés en lip(o)- dans la poésie lyrique grecque: étude d'un micro-système lexical. Philologus, vol. 141, 1997, pp. 145-148.

ITSUMI, I. What's in a line? Papyrus Formats and Hephaestionic Formulae. In FINGLASS, P. J., COLLARD, C. e RICHARDSON, N. J. (edd.) Hesperos. Studies in Ancient Greek Poetry presented to M. L. West on his Seventieth Birthday. Oxford: Oxford University Press, 2007, pp. 306-325.

KANTZIOS, I. The Trajectory of Archaic Greek Trimeters. Lieden, Boston: Brill, 2005.

LASSERRE, F. Les Épodes d' Archiloque. Paris: Belles Lettres, 1950.

LÉVY, E. Astos et polites d' Homère à Hérodote. Ktéma, vol. 10, [1985] 1988, pp. 53-66.

MARTINO, F. de e VOX, O. Lirica Greca. Vol. I: Prontuari e lirica dorica; Vol. II: Lirica ionica; Vol. III: Lirica eolica. Bari: Levante, 1996.

McGLEW, J. Tyranny and Political Culture in Ancient Greece. Ithaca e London: Cornell University Press, 1993.

MEDAGLIA, S. M. Note di esegesi archilochea. Roma: Accademia Nazionale dei Lincei, 1982.

MIRALLES, C. e J. PÒRTULAS. Archilochus and the Iambic Poetry. Roma: Dell' Ateneo, 1983.

MOULTON, C. Aristophanic Poetry. Göttingen: Vandenhoeck \& Ruprecht, 
1981.

MURRU, F. Le polúptoton de Léophile. Eos, vol. 67, 1979, pp. 183-9.

NAGY, G. The Best of the Achaeans: Concepts of the Hero in Archaic Greek Poetry. Baltimore: Johns Hopkins University Press, 1979.

OSBORNE, R. Early Greek Colonization? The nature of Greek Settlement in the West. In FISHER, N. e H. van WEES (edd.) Archaic Greece: New Approaches and New Evidence. London: Duckworth, 1998, pp. 251-69.

PAGE, D. L. Archilochus and the Oral Tradition. In POUILLOUX, J. et al. (Org.) Archiloque: Sept exposés et discussions. Entretiens sur l'Antiquité Classique X (Vandoevres, Genebra, 26/8-3/9/1963). Genebra: Fondation Hardt, 1964, pp. 118-79.

PICKARD-CAMBRIDGE, A. Dithyramb, Tragedy and Comedy. Oxford: Oxford University Press, 1927.

PIPPIN-BURNETT, A. Three Archaic Poets: Archilochus, Alcaeus, Sappho. Cambridge, Mass.: Harvard University Press, 1983.

RAAFLAUB, K. A. A historian's headache; How to read 'Homeric society'?, In FISHER, N. and H. van WEES (edd.) Archaic Greece: New Approaches and New Evidence. London: Duckworth, 1998, pp. 169-193.

RACKHAM, H. Aristotle, Politics, Vol. 21. Cambridge, MA, Harvard University Press; London, William Heinemann Ltd., 1944.

RANKIN, H. D. Aristotle on Archilochus. L'Antiquité classique, vol. 46, 1961, pp. 165-8.

RANKIN, H. D. Archilochus of Paros. Park Ridge, N.J.: Noyes Press, 1977.

ROSEN, R. M. Old Comedy and the Iambographic Tradition. Atlanta: Scholars Press, 1988.

ROSEN, R. M. Making Mockery; The Poetics of Ancient Satire. Oxford, New York: Oxford University Press, 2007.

SCHERER, A. Die Sprache des Archilochos, In POUILLOUX, J. et al. (Org.) Archiloque: Sept exposés et discussions. Entretiens sur l'Antiquité Classique X (Vandoevres, Genebra, 26/8-3/9/1963). Genebra: Fondation Hardt, 1964, pp. 89-107.

SHAPIRO, H. A. (ed.) The Cambridge Companion to Archaic Greece. New 
York: Cambridge University Press, 2007.

STOREY, I. C. Fragments of Old Comedy. Cambridge, Mass; London: Harvard University Press, 2011.

WEST, M. L. Studies in Greek Elegy and Iambus. Berlin, New York: de Gruyter, 1974.

WEST, M. L. Greek Lyric Poetry. Trad. Oxford: Oxford University Press, 1993.

ZANETTO, G. Iambic Patterns in Aristophanic Comedy. In CAVARZERE, A., ALONI, A. e BARCHIESI, A. (edd.) Iambic Ideas; Essays on a Poetic Genre from Archaic Greece to the Late Roman Empire. Lanham, Boulder, New York, Oxford: Rowman \& Littlefield, 2001, pp. 65-76.

Abbreviated names follow LSJ.

FGrH JACOBY, F. (ed.) Fragmente der griechischen Historiker. Berlin, Leiden: Brill, 1923-1958.

FHG MÜLLER, C. (ed.) Fragmenta Historicorum Graecorum. Paris: Didot, 1841-1870.

IEG WEST, M. L. (ed.) Iambi et Elegi Graeci ante Alexandrum cantati. Oxford: Oxford University Press, 1971 (1 a ed.), 1998 (2a ed.).

K.-A. KASSEL, R. e AUSTIN, C. (ed.) Poetae Comici Graeci. Berlin, New York: de Gruyter, 1989.

PMG PAGE, D. L. (ed.) Poetae Melici Graeci. Alcmanis, Stesichori, Ibyci, Anacreontis, Simonidis, Corinnae, poetarum minorum reliqvias, carmina popvlaria et convivalia quaque adespota fervntor. Oxford: Oxford University Press, 1962.

V. VOIGT, E.-M. Sappho et Alcaeus: fragmenta. Amsterdã: Athenaeum, Polak \& Van Gennep, 1971. 